\title{
PEMODELAN PADA PROSES PENGERINGAN MEKANIS TEPUNG KASAVA DENGAN MENGGUNAKAN PNEUMATIC DRYER: HUBUNGAN FINENESS MODULUS DENGAN VARIABEL PROSES PENGERINGAN
}

\author{
Modelling on Mechanical Cassava Flour Drying Process by Using Pneumatic Dryer: \\ Correlation of Fineness Modulus and Drying Process Variable \\ Yus Witdarko', Nursigit Bintoro², Bandul Suratmo², Budi Rahardjo² \\ ${ }^{1}$ Jurusan Teknik Pertanian, Fakultas Pertanian, Universitas Musamus, Jl. Kamizaun, Mopah Lama, Merauke 99611 \\ ${ }^{2}$ Jurusan Teknik Pertanian, Fakultas Teknologi Pertanian, Universitas Gadjah Mada, \\ J1. Flora No. 1, Bulaksumur, Yogyakarta 55281 \\ Email: buluhbulan@gmail.com
}

\begin{abstract}
ABSTRAK
Metode pengeringan yang diterapkan dalam industri pembuatan tepung salah satunya adalah pneumatic drying. Berbagai macam variabel baik dari sifat-sifat bahan yang dikeringkan maupun kondisi proses pengeringan sangat mempengaruhi kualitas hasil pengeringan. Fineness Modulus (FM) dan diameter tepung rata-rata merupakan variabel-variabel yang penting dalam penentuan kualitas dari tepung. Tujuan dari penelitian ini adalah untuk mencari hubungan matematis antara FM dengan variabel-variabel kondisi proses pengeringan pneumatik. Untuk dapat mewujudkan tujuan tersebut telah dirancang peralatan pneumatic drying dan dilakukan pengujian dengan berbagai macam variasi perlakuan seperti kapasitas input, kecepatan udara pengering, diameter partikel tepung, dan temperatur udara pengering.
\end{abstract}

Kata kunci: Tepung ubi kayu, pneumatic drying, analisis dimensi, fineness modulus

\begin{abstract}
One of the drying methods, which are applied in the industry of flour production, is that pneumatic drying. A wide variety of the variables that are from both of the characteristics of the dried material and drying process condition greatly affect the quality of drying result. Fineness Modulus (FM) and average diameter of flour are important variables in determining the quality of the flour. The objectives of this research was to formulatea mathematical relationship between various pneumatic drying process variables with the fineness modulus of the materials of cassava flour by applying dimensional analysis. In order to realize this goal, pneumatic drying equipment has been designed and tested with a wide variety of treatments such as the input capacity, drying air velocity, particle's flour diameter, and temperature of air dryer as well.
\end{abstract}

Keywords: Cassava flour, pneumatic drying, dimensional analysis, fineness modulus

\section{PENDAHULUAN}

Sebagai salah satu bahan pangan, tepung gandum umumnya digunakan untuk membuat makanan seperti roti, kue, biskuit, dan lain-lain. Tepung gandum juga merupakan bahan baku bihun, campuran pembuatan mie yang digunakan dalam industri, serta untuk membuat makanan gorengan. Permintaan tepung gandum yang terus meningkat setiap tahun, diharapkan dapat disubstitusi dengan tepung-tepung dari tanaman pangan lokal seperti jagung, ubi kayu, dan ubi jalar untuk mengurangi pengeluaran devisa negara. Teknologi pengolahan tepung-tepung dari tanaman pangan lokal masih sangat terbatas, maka perlu berbagai macam informasi ilmiah untuk meningkatkan proses pengolahan tepung.

Salah satu proses yang sangat penting dalam produksi tepung adalah pengeringan. Menurut Verdijck dkk. (1998), pengeringan adalah salah satu operasi paling umum dalam industri makanan dan didefinisikan sebagai pemisahan zat cair 
dari zat padat melalui penguapan. Pengeringan merupakan difusi yang dikontrol, yang menyatakan secara tidak langsung bahwa resistensi dari aliran massa di dalam partikel zat padat menentukan kecepatan pengeringan. Menurut Pelegrina dan Crapiste (2001), temperatur udara pengering menurun sepanjang pengering disebabkan oleh transfer panas ke bahan.

Pengeringan tepung secara konvensional pada umumnya dilakukan dengan menggunakan sinar matahari. Banyak hambatan pada pengeringan dengan menggunakan sinar matahari seperti cuaca yang tidak menentu, kontaminasi kotoran, temperatur berubah-ubah dan lain-lain.Apalagi pada bulan-bulan dengan curah hujan yang tinggi maka tepung yang sudah diolah tidak dapat segera dikeringkan sehingga mengakibatkan mutu tepung menurun.

Salah satu metode pengeringan yang diterapkan dalam industri pembuatan tepung adalah pneumatic drying. Pada pengeringan dengan sistem pneumatic drying, kalor diangkut dan dipindahkan ke bahan tepung secara konveksi. Pengering pneumatik lebih sesuai digunakan sebagai pengering yang cepat untuk menghilangkan kadar air pada permukaan bahan, karena hal ini hanya membutuhkan waktu pengeringan yang singkat (Bunyawanichakul dkk., 2007). Panas yang diterima bahan harus dikontrol karena proses pengeringan terjadi dalam waktu singkat. Walaupun nilai tukar panas tinggi, suhu pada bahan tidak mencapai suhu udara pengering karena kehilangan panas akibat penguapan sangat cepat (Fumihiko dkk., 2007). Aliran panas (konveksi) antara gas dan partikel sangat tinggi mengakibatkan waktu panas pengeringan bahan sangat cepat (Mujumdar, 1987). Berbagai macam variabel baik dari sifat-sifat bahan yang dikeringkan maupun kondisi proses pengeringan sangat mempengaruhi kualitas hasil pengeringan. Perlu dicari hubungan berbagai macam parameter dari produk yang dikeringkan dengan kondisi proses maupun desain mesin pengeringnya untuk mendapatkan kualitas dari produk yang dikeringkan sesuai dengan yang diharapkan. Untuk dapat mencari hubungan kuantitatif antara produk tepung dengan kondisi proses maupun desain mesin pengering dalam proses pengeringan pneumatik dapat digunakan analis dimensi. Lebih lanjut dengan analisis dimensi ini proses perancangan mesin pengering pneumatik tersebut akan dapat dilakukan dengan teliti dan terarah.

Analisis dimensi mempunyai langkah-langkah yang sederhana, tetapi kemanfaatannya sangat besar yang memungkinkan peneliti merancang peralatan atau mesinmesin dalam skala kecil, tidak mahal biayanya, dantidak sukar dilaksanakan di laboratorium. Kesederhanaan konsep ini memberi pengaruh yang besar dan pendekatan yang efektif untuk memecahkan masalah kondisi di industri. Konsep ini didasarkan pada suatu gagasan bahwa suatu persamaan harus mempunyai dimensi homogen yaitu solusinya harus di dalam variasi untuk perubahan dalam pengukuran suatu satuan.
Menurut Lam (2004), di dalam masalah-masalah di luar teknik elektronik ada tiga satuan dasar yaitu massa, panjang, dan waktu.

Salah satu parameter penting dari persyaratan kualitas tepung adalah tingkat kehalusan tepung tersebut.Fineness Modulus (FM) adalah suatu index yang digunakan untuk menyatakan tingkat kehalusan suatu bahan padatan curah seperti tepung, pasir, semen, dan lain-lain. Fineness Modulus yang dikembangkan oleh Abrams untuk mengerjakan beton tetapi dapat digunakan pada mesin penggiling (Henderson, 1961). Tingkat kehalusan umumnya dibagi menjadi kasar, sedang, dan halus, dimana semakin halus suatu bahan akan mempunyai nilai $F M$ yang semakin kecil. $F M$ ditentukan dengan pengayakkan menggunakan satu seri ayakan dengan mesh atau ukuran lubang tertentu yang telah ditetapkan dan pada bahan tepung-tepungan biasanya menggunakan suatu seri ayakan Tyler. Ayakan ini digerakkandengan getaran yang dihasilkan oleh mesin vibrator.Akibat dari getaran ini maka partikel yang diayak lolos ke bawah sesuai kemampuan lolosnya yang tergantung pada diameter partikel.Secara matematis Fineness Modulus bahan tepung hasil pengeringan dapat dihitung dengan persamaan (1).

$$
F M=\frac{\text { Jumlah total \% tertinggal komulatif }}{100}
$$

Berdasarkan nilai $F M$ ini, maka dapat juga dihitung diameter rata-rata (2)

$$
D=0,0041(2)^{F M}(\text { inch })
$$

Atau dalam satuan mm menjadi

$$
D=0,104(2)^{F M}(\mathrm{~mm})
$$

Secara umum tujuan penelitian ini adalah untuk mendapatkan hubungan kuantitatif antara berbagai macam variabel yang terlibat dalam proses pengeringan tepung secara pneumatik. Secara lebih khusus difokuskan untuk memperformulasikan hubungan matematis antara Fineness Modulus tepung yang dihasilkan dengan berbagai macam variabel proses pengeringan pneumatik dengan menggunakan analisis dimensi.

\section{METODE PENELITIAN}

\section{Landasan Teori}

Analisis dimensi merupakan suatu metode analisis yang dapat digunakan untuk menghubungkan berbagai macam variabel yang terlibat dalam suatu proses. Untuk menerapkan analisis tersebut dalam penelitian ini, maka diperlukan 
berbagai informasi terkait dengan variabel-variabel yang mempengaruhi proses pneumatic drying yang diteliti. Pada penelitian ini akan dilakukan analisis dimensi untuk menghubungkan secara matematis antara $F M$ tepung hasil pengeringan dengan berbagai macam variabel terkait dalam proses pengeringan tersebut.

Untuk itutelah dipilih beberapa macam variabel yang diduga mempunyai pengaruh atau hubungan tertentu dengan $F M$. Independen variabel dan dependen variabel terpilih untuk analisis dimensi dalam formulasi persamaan $F M$ dapat dilihat pada Tabel 1 .

Tabel 1. Independen dan dependen variabel pada analisis dimensi $F M$

\begin{tabular}{llll}
\hline \multicolumn{1}{c}{ Variabel } & Simbol & Satuan & Dimensi \\
\hline Independen variabel & & & \\
a. Kapasitas input bahan & $\mathrm{Q}_{\mathrm{i}}$ & $\mathrm{kg} / \mathrm{s}$ & $\mathrm{ML}^{-1}$ \\
b. Kapasitas output Bahan & $\mathrm{Q}_{\mathrm{o}}$ & $\mathrm{kg} / \mathrm{s}$ & $\mathrm{ML}^{-1}$ \\
c. Diameter partikel & $\mathrm{D}_{\mathrm{pr}}$ & $\mathrm{m}$ & $\mathrm{L}$ \\
d. Temperatur bahan awal & $\mathrm{T}_{\mathrm{bo}}$ & ${ }^{\circ} \mathrm{C}$ & $\mathrm{O}$ \\
e. Kecepatan udara pengering & $\mathrm{V}_{\mathrm{u}}$ & $\mathrm{m} / \mathrm{s}$ & $\mathrm{LT}^{-1}$ \\
f. Temperatur udara pengering & $\mathrm{T}_{\mathrm{u}}$ & ${ }^{\circ} \mathrm{C}$ & $\mathrm{O}$ \\
g. Waktu & $\theta$ & $\mathrm{s}$ & $\mathrm{T}$ \\
h. Gravitasi & $\mathrm{g}$ & $\mathrm{m} / \mathrm{s}^{2}$ & $\mathrm{LT}^{-2}$ \\
\hline Dependen & & & \\
a. Fineness Modulus & $F M$ & & \\
\hline
\end{tabular}

Dari variabel-variabel tersebut dapat ditulis hubungan fungsional sebagai berikut:

$$
\begin{aligned}
& F M=\mathrm{f}\left(\mathrm{Q}_{\mathrm{i}}, \mathrm{Q}_{\mathrm{o}}, \mathrm{V}_{\mathrm{u}}, \mathrm{D}_{\mathrm{pr}}, \theta, \mathrm{g}, \mathrm{T}_{\mathrm{u}}, \mathrm{T}_{\mathrm{bo}}\right) \\
& \pi=\mathrm{Q}_{\mathrm{i}}{ }^{\mathrm{k} 1} \mathrm{Q}_{\mathrm{o}}{ }^{\mathrm{k} 2} \mathrm{~V}_{\mathrm{u}}{ }^{\mathrm{k} 3} \mathrm{D}_{\mathrm{pr}}{ }^{\mathrm{k} 4} \theta^{\mathrm{k} 5} \mathrm{~g}^{\mathrm{k} 6} \mathrm{~T}_{\mathrm{u}}{ }^{\mathrm{k} 7} \mathrm{~T}_{\mathrm{bo}}{ }^{\mathrm{k} 8}
\end{aligned}
$$

Dari analisis dimansi terdapat empat persamaan dengan delapan bilangan yang tidak diketahui nilainya. Menurut Randall (2000), pada analisis dimensi bilangan yang tidak diketahui nilainya diberi nilai-nilai tertentu sehingga dihasilkan dimensionless group. Pada analisis dimensi ini diambil k1, k3, k5, dan $\mathrm{k} 7$ diberi nilai-nilai tertentu sehingga dihasilkan lima kelompok $\pi$ (dimensionless product) sebagai berikut:

$$
\begin{aligned}
& \pi_{1}=F M \\
& \pi_{2}=\frac{Q_{i}}{Q_{o}} \\
& \pi_{3}=\frac{V_{u}}{g^{1 / 2} D_{p r}^{1 / 2}} \\
& \pi_{4}=\frac{\theta \cdot g^{1 / 2}}{D_{p r}^{1 / 2}} \\
& \pi_{5}=\frac{T_{u}}{T_{b}}
\end{aligned}
$$

Untuk mempermudah pelaksanan penelitian serta analisis lebih lanjut maka $\pi_{3}$ diubah dengan cara membagi $\pi_{3}$ dengan $\pi_{4}$ sehingga dihasilkan $\pi_{3}$ baru $\frac{v_{u}}{\theta \cdot g}$. Selanjutnya $\pi_{4}$ diubah dengan membulatkan pangkat menjadi $\frac{\theta^{2} g}{D_{p r}}$

Berdasarkan Buckingham's $\pi$-theorem menurut Sonin (2001), bahwa nilai-nilai $\pi$ tersebut kemudian disusun dalam bentuk hubungan fungsionalsebagai berikut:

$$
F M=C \cdot\left(\frac{Q_{i}}{Q_{o}}\right)^{a}\left(\frac{V_{u}}{\theta \cdot g}\right)^{b}\left(\frac{\theta^{2} \cdot g}{D_{p r}}\right)^{c}\left(\frac{T_{u}}{T_{b o}}\right)^{d}
$$

Nilai-nilai konstanta C, a, b, c, d dapat ditentukan berdasarkan data-data hasil penelitian yang dilakukan dengan merubah persamaan (11) dalam bentuk log (Gunther dan Morgado, 2003).

$\log \pi_{1}=\log C+a \log \left(\pi_{2}\right)+b \log \left(\pi_{3}\right)+c \log \left(\pi_{4}\right)+d \log \left(\pi_{5}\right)$

\section{Bahan}

Bahan utama yang digunakan untuk penelitian ini adalah singkong (ubi kayu) jenis putih diperoleh dari pasar Telo, Yogyakarta sebanyak 200 kg.Ubi kayu kemudian dikupas dan dicuci secara manual kemudian diparut dengan mesin pemarut.Untuk mengurangi kadar air, parutan ubi kayu tersebut dikempa dengan mesin penekan hidrolik. Pengempaan dilakukan untuk setiap 1000 gram berat parutan dengan tekanan $50 \mathrm{~kg} / \mathrm{cm}^{2}$ selama 10 menit. Parutan ubi kayu yang sudah dikempa dihancurkan.Hasil tepung basah tersebut kemudian diayak dengan ayakanukuran 60 mesh, 80 mesh dan 100 mesh digunakan sebagai variasi perlakuan ukuran partikel tepung basah.Proses selanjutnya tepung tersebut dikeringkan dengan flash dryer yang telah dikonstruksi dalam dua kali proses.

\section{Alat}

Peralatan utama yang digunakan dalam penelitian ini berupa peralatan pengering mekanis tipe pneumatik (flash dryer) yang dapat dilihat pada Gambar 1.Beberapa bagian utama dari peralatan ini adalah tungku pemanas udara pengering dengan bahan bakar gas LPG menggunakan burner tekanan tinggi yang ditempatkan secara horizontal dalam kotak tungku.Blower mengisap udara panas dari tungku dan menyalurkan ke dalam pipa pengering sepanjang sembilan meter.Laju dan kecepatan aliran udara dapat diatur dengan mengatur lebar bukaan inlet tungku. Pemasukan bahan yang akan dikeringkan dilakukan lewat suatu feeder yang dilengkapi dengan blower pendorong ke saluran pipa pengering. Proses pengeringan terjadi di sepanjang saluran pipa pengeringdan untuk memisahkan antara udara panas dan tepung kering dilakukan di dalam cyclone yang dipasang pada ujung akhir pipa pengering. 


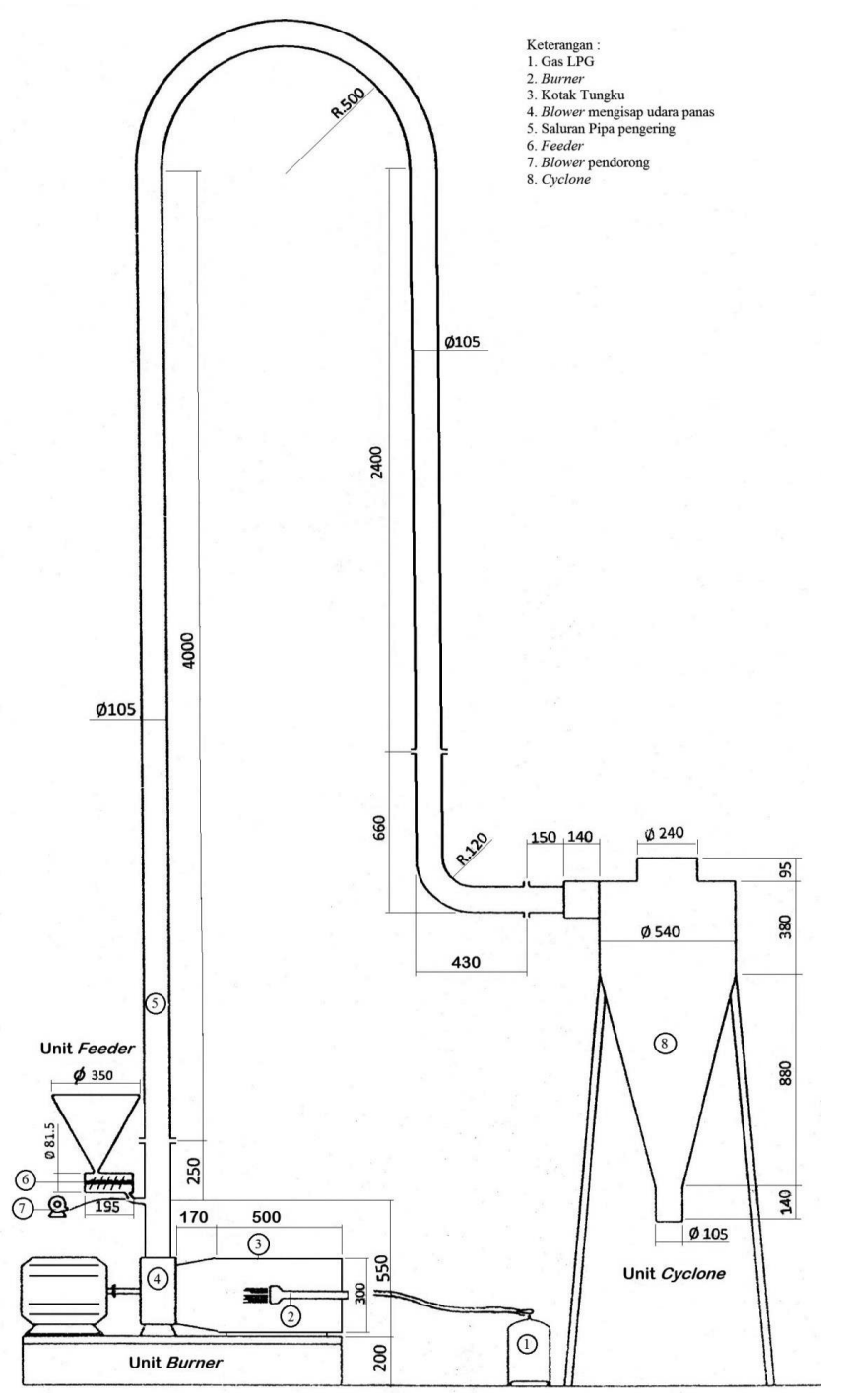

Gambar 1. Peralatan pengering mekanis tipe pneumatik (flash drying)

\section{Prosedur Penelitian}

Pelaksanaan penelitian dimulai dengan menghidupkan peralatan pengering, kemudian setelah suhu pengeringan mencapai nilai yang ditetapkan, bahan parutan ubi kayu hasil pengempaan yang telah dihancurkan dimasukkan ke dalam mesin pengering. Tepung hasil pengeringan ditampung dengan menggunakan wadah yang ditaruh di bawah cyclone.

Cara mendapatkan hubungan antar dimensionless product misal antara $\mathrm{p}_{1}(F M)$ dengan $\mathrm{p}_{2}$, maka dimensionless product $(\pi)$ yang lain ditahan konstan. Demikian juga saat mendapatkan hubungan $\mathrm{p}_{1}(F M)$ dengan $\mathrm{p}_{3}$, maka $\pi$ yang lan ditahan konstan. Hal ini juga dilakukan untuk hubungan $\mathrm{p}_{1}$ dengan $\pi_{4}$ dan $\mathrm{p}_{1}$ dengan $\pi_{5}$. Kemudian $\pi_{1}, \pi_{2}, \pi_{3}, \pi_{4}$, dan $\pi_{5}$ dilogkan. Selanjutnya hasil log dengan menggunakan program excel, dianalisis dengan multiplelinier regression. Pada $\mathrm{p}_{2}$ yang divariasi variasi kapasitas input bahan $\left(\mathrm{Q}_{\mathrm{i}}\right)$ yaitu 0,$0371 ; 0,0509 ; 0,0616 \mathrm{~kg} / \mathrm{s}$, sedang $\mathrm{p}_{3}$ yang divariasi kecepatan aliran udara pengering $\left(\mathrm{V}_{\mathrm{u}}\right)$ yaitu 17,$2 ; 18,1$; dan $19,29 \mathrm{~m} / \mathrm{s}$, kemudian $\pi_{4}$ yang divariasi diameter bahan parutan $\left(D_{p r}\right)$ yaitu 0,$3666 ; 0,2644 ; 0,1811 \mathrm{~mm}$ serta $\pi_{5}$ variasi temperatur udara pengering $\left(\mathrm{T}_{\mathrm{u}}\right)$ yaitu $145^{\circ} ; 160^{\circ}$; dan $175^{\circ} \mathrm{C}$. Variabel lain seperti kapasitas output tepung dan lama waktu pengeringan total diukur langsung pada saat penelitian. Nilai $F M$ dari tepung hasil pengeringan diukur setelah pengeringan selesai dengan cara pengayakan.

\section{HASIL DAN PEMBAHASAN}

Dari pelaksanaan penelitian ini diperoleh hubungan antara $F M$ dengan beberapa variabel yang diteliti seperti disajikan pada Tabel 2

Tabel 2. Hubungan antara $F M$ dengan variabel $\mathrm{Q}_{\mathrm{i}}, \mathrm{V}_{\mathrm{u}}, \mathrm{D}_{\mathrm{pr}}$, dan $\mathrm{T}_{\mathrm{u}}$

\begin{tabular}{|c|c|c|c|c|c|}
\hline \multirow{2}{*}{ Variabel } & \multirow{2}{*}{$\begin{array}{c}\text { Variasi } \\
\text { perlakuan }\end{array}$} & \multicolumn{4}{|c|}{$F M$} \\
\hline & & 1 & 2 & 3 & Rata-rata \\
\hline \multirow[t]{3}{*}{$\mathrm{Q}_{\mathrm{i}}$} & $0,0371 \mathrm{~kg} / \mathrm{s}$ & 1,3162 & 1,4206 & 1,3021 & 1,3463 \\
\hline & $0,0509 \mathrm{~kg} / \mathrm{s}$ & 1,3521 & 1,3128 & 1,3671 & 1,3440 \\
\hline & $0,0616 \mathrm{~kg} / \mathrm{s}$ & 1,3390 & 1,2926 & 1,2556 & 1,2957 \\
\hline \multirow[t]{3}{*}{$\mathrm{V}_{\mathrm{u}}$} & $17,12 \mathrm{~m} / \mathrm{s}$ & 1,3707 & 1,3805 & 1,3838 & 1,3783 \\
\hline & $18,10 \mathrm{~m} / \mathrm{s}$ & 1,3521 & 1,3128 & 1,3671 & 1,3440 \\
\hline & $19,29 \mathrm{~m} / \mathrm{s}$ & 1,3249 & 1,3231 & 1,3084 & 1,3188 \\
\hline \multirow[t]{3}{*}{$\mathrm{D}_{\mathrm{pr}}$} & $0,0003666 \mathrm{~m}$ & 1,3162 & 1,4206 & 1,3021 & 1,3463 \\
\hline & $0,0002644 \mathrm{~m}$ & 1,3521 & 1,3128 & 1,3671 & 1,3440 \\
\hline & $0,0001811 \mathrm{~m}$ & 0,8142 & 0,7988 & 0,7834 & 0,7988 \\
\hline \multirow[t]{3}{*}{$\mathrm{T}_{\mathrm{u}}$} & $145^{\circ} \mathrm{C}$ & 1,4850 & 1,4804 & 1,4856 & 1,4837 \\
\hline & $160^{\circ} \mathrm{C}$ & 1,3521 & 1,3128 & 1,3671 & 1,3440 \\
\hline & $175^{\circ} \mathrm{C}$ & 1,1490 & 1,1278 & 1,1460 & 1,1409 \\
\hline
\end{tabular}

Dengan menggunakan persamaan (12) maka dapat diperoleh nilai-nilai konstanta $\mathrm{C}$, a, b, c, dan $\mathrm{d}$ yaitu $12024,8113,-0,0585,-0,3112,-0,4776,-1,3504$ sehingga diperoleh hubungan matematis antara $F M$ dengan variabelvariabel proses pengeringan dapat ditulis seperti pada persamaan (13).

$F M=12044,8113 \cdot\left(\frac{Q_{i}}{Q_{o}}\right)^{-0,0585} \cdot\left(\frac{V_{u}}{g \cdot \theta}\right)^{-0,3112} \cdot\left(\frac{\theta^{2} \cdot g}{D_{p r}}\right)^{-0,4776} \cdot\left(\frac{T_{u}}{T_{b o}}\right)^{-1,3504}$

Beberapa karakteristik dari persamaan ini dapat dilihat dari hubungan antara dependen dan independen variabel dari persamaan tersebut.Hubungan rasio laju input terhadap laju output dengan FM dapat dilihat pada Gambar 2. FM akan cenderung turun dengan turunnya rasio $\mathrm{Q}_{\mathrm{i}}$ terhadap $\mathrm{Q}_{\mathrm{o}}$. Hal ini menunjukkan bahwa pada laju output $\left(\mathrm{Q}_{\mathrm{o}}\right)$ yang tetap, dengan mengurangi laju input $\left(\mathrm{Q}_{\mathrm{i}}\right)$, maka akan dihasilkan tepung yang semakin halus ( $F M$ semakin rendah). Kondisi ini disebabkan karena dengan semakin kecil laju input maka 
proses pengeringan akan semakin efektif sehingga uap air dalam bahan secara efektif dapat dikeluarkan dari tepung, maka partikel-partikel tepung akan semakin terurai (tidak saling lengket) sehingga derajat kehalusannya meningkat.

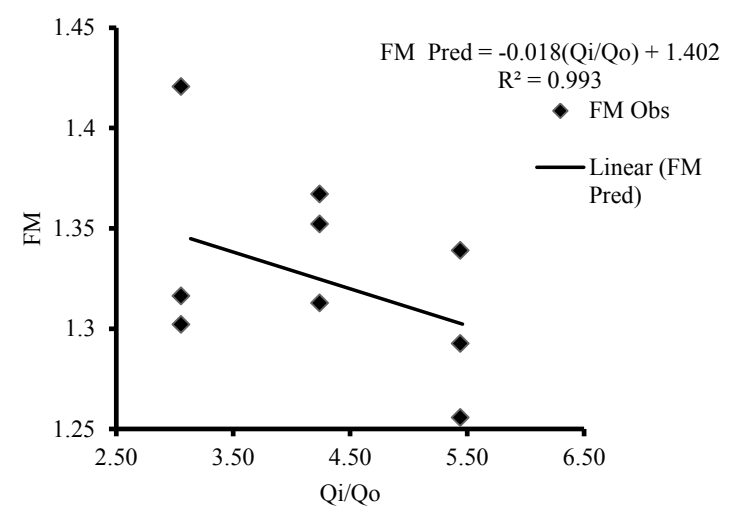

Gambar 2. Grafik hubungan $\mathrm{Q}_{\mathrm{i}} / \mathrm{Q}_{\mathrm{o}}$ dengan $F M$

Gambar 3 menunjukkan hubungan rasio kecepatan udara pengering terhadap waktu pengeringan dengan $F M$. Dapat dilihat bahwa $F M$ akan cenderung turun dengan turunnya $\mathrm{V}_{\mathrm{u}}$ terhadap $\theta$. Hal ini menunjukkan bahwa pada waktu $(\theta)$ yang tetap, dengan mengurangi kecepatan udara pengering $\left(\mathrm{V}_{\mathrm{u}}\right)$, maka akan dihasilkan tepung yang semakin halus. Kondisi ini disebabkan karena dengan semakin lambat kecepatan udara pengering maka proses pengeringan akan semakin lama terjadi sehingga uap air dalam bahan dapat dikeluarkan lebih banyak dan pada akhirnya akin dihasilkan tepung yang lebih halus.

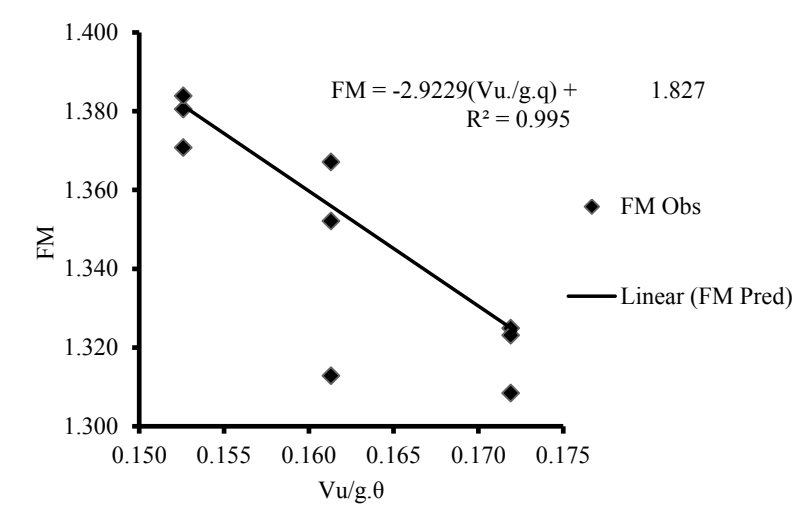

Gambar 3. Grafik hubungan antara $\mathrm{V}_{\mathrm{u}}$ g. $\theta$ dengan $F M$

Hubungan rasio diameter partikel terhadap waktu dengan $F M$ dapat dilihat pada Gambar 4. FM akan cenderung turun dengan turunnya rasio $\mathrm{D}_{\mathrm{pr}}$ terhadap $\theta$. Hal ini menunjukkan bahwa pada $(\theta)$ yang tetap, dengan mengurangi ukuran diameter partikel $\left(\mathrm{D}_{\mathrm{pr}}\right)$, maka akan dihasilkan tepung yang semakin halus ( $F M$ semakin rendah). Keadaan ini disebabkan karena dengan semakin kecil diameter partikel tepung akan semakin singkat waktunya uap air dalam bahan dapat dikeluarkan dari bahan tepung, maka partikel-partikel tepung akan semakin cepat terurai dan cepat kering sehingga derajat kehalusannya meningkat.

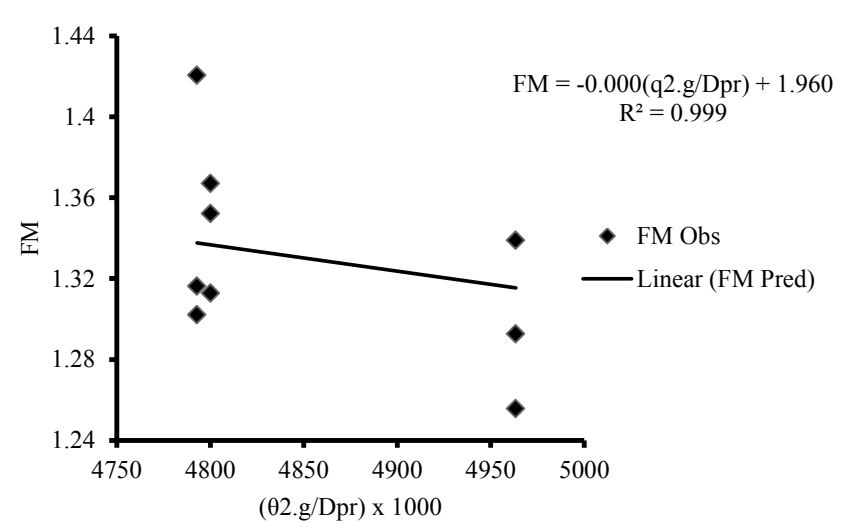

Gambar 4. Grafik hubungan antara $\theta^{2} \cdot \mathrm{g} / \mathrm{D}_{\mathrm{pr}}$ dengan $F M$

Hubungan rasio temperatur udara pengering terhadap temperatur bahan dengan $F M$ dapat dilihat pada Gambar 5. $F M$ akan cenderung turun dengan turunnya rasio $\mathrm{T}_{\mathrm{u}}$ terhadap $\mathrm{T}_{\mathrm{bo}}$. Hal ini menunjukkan bahwa pada temperatur bahan $\left(\mathrm{T}_{\mathrm{bo}}\right)$ yang tetap, dengan menaikkan temperatur udara pengering $\left(\mathrm{T}_{\mathrm{u}}\right)$, maka akan dihasilkan tepung yang semakin halus (FM semakin rendah). Keadaan ini disebabkan karena dengan semakin tinggi temperatur udara pengering maka proses pengeringan akan semakin mampu menguapkan air dalam jumlah yang lebih banyak sehingga akan dihasilkan tepung dengan derajat kehalusan yang lebih tinggi.

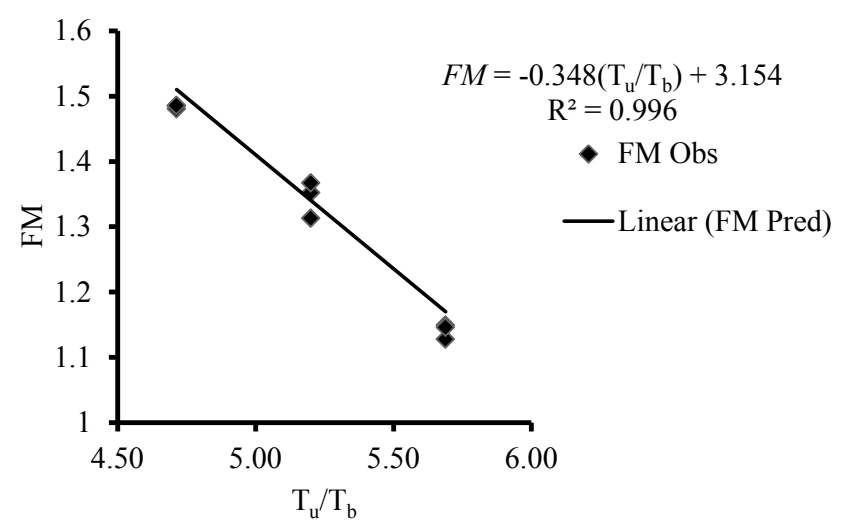

Gambar 5. Grafik hubungan antara $\mathrm{T}_{\mathrm{u}} / \mathrm{T}_{\mathrm{b}}$ dengan $F M$

Untuk mengevaluasi pengaruh dimensionless product terhadap nilai $F M$ maka telah dilakukan uji sensitivitas dengan menaikkan dan menurunkan masing-masing nilai dimensionless product tersebut $10 \%$. Berdasarkan hasil uji sensitivitas tersebut dapat diketahui bahwa secara berturutturut dimensionless product yang paling berpengaruh 
terhadap nilai $F M$ adalah $\mathrm{T}_{\mathrm{u}} / \mathrm{T}_{\mathrm{bo}}, \theta^{2} \cdot \mathrm{g} / \mathrm{D}_{\mathrm{pr}}, \mathrm{V}_{\mathrm{u}} / \mathrm{g} . \theta$, dan $\mathrm{Q}_{\mathrm{i}} / \mathrm{Q}_{\mathrm{o}}$, masing-masing berturut-turut $13,683 \%, 4,805 \%, 3,128 \%$, dan $0,587 \%$.

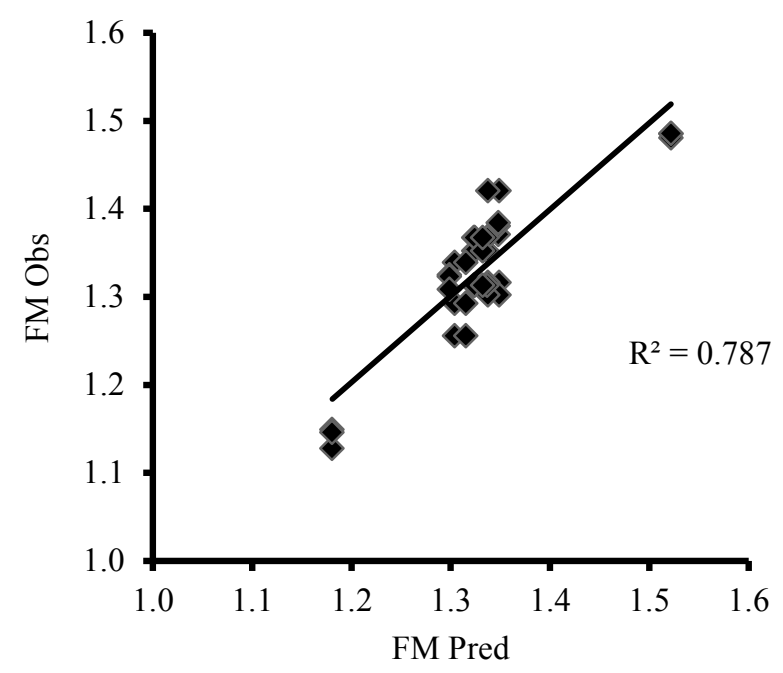

Gambar 6. Grafik hubungan $F M$ prediksi dengan $F M$ observasi

Hubungan antara $F M$ prediksi dan $F M$ observasi dapat dilihat pada Gambar 6. Dapat dilihat bahwa hubungan antara kedua nilai tersebut sangat dekat dengan nilai $R^{2}=0,787$ yang cukup dekat dengan satu. Hal ini menunjukkan bahwa persamaan $F M$ yang dihasilkan akan dapat digunakan untuk memprediksi nilai kehalusan butir tepung hasil pneumatic drying aktual secara baik.

Berdasarkan hasil dari persamaan $F M$ yang diperoleh (13), maka persamaan untuk penentuan diameter partikel tepung rata-rata adalah

$D=0.104(2)\left\{12044,8113\left(\frac{Q_{i}}{Q_{o}}\right)^{-0,0585}\left(\frac{V u}{g . \theta}\right)^{-0,3112}\left(\frac{\theta^{2} g}{D_{p r}}\right)^{-0,4776}\left(\frac{T_{u}}{T_{b o}}\right)^{-1,3504}\right\}$

Untuk mengevaluasi pengaruh dimensionless product terhadap nilai D maka telah dilakukan uji sensitivitas dengan menaikkan dan menurunkan masing-masing nilai dimensionless product tersebut $10 \%$. Berdasarkan hasil uji sensitivitas tersebut diketahui secara berturut-turut nilai dimensionless product yang paling berpengaruh terhadap nilai Dadalah $\mathrm{T}_{\mathrm{u}} / \mathrm{T}_{\mathrm{bo}}, \theta^{2} \cdot \mathrm{g} / \mathrm{D}_{\mathrm{pr}}, \mathrm{V}_{\mathrm{u}} / \mathrm{g} . \theta$, dan $\mathrm{Q}_{\mathrm{i}} / \mathrm{Q}_{\mathrm{o}}$, dimana prosentase pengaruh dari masing-masing dimensionless product tersebut terhadap $F M$ berturut-turut $12,987 \%$, 4,446\%, 2,859\%, dan $0,540 \%$. Dari sini dapat diketahui bahwa kehalusan tepung dalam proses pneumatic drying sangat sensitif terhadap perubahan temperatur udara pengering dan temperatur bahan awal yang dikeringkan.

Berdasarkan persamaan (14) maka hubungan antara diameter partikel tepung aktual dengan diameter tepung prediksi dapat dilihat pada Gambar 7 berikut ini.

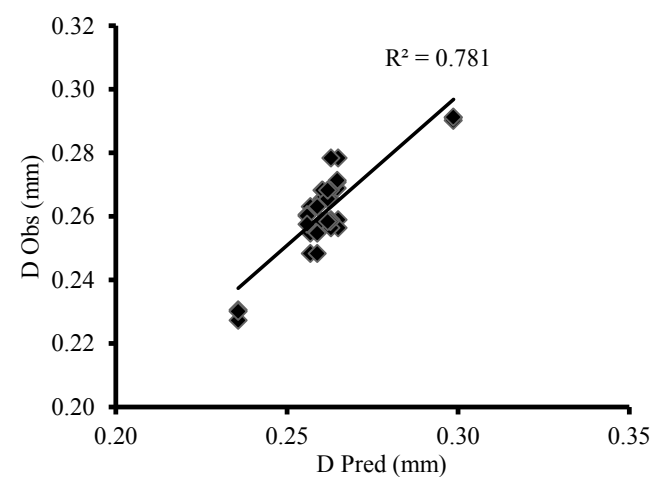

Gambar 7. Grafik hubungan D prediksi dengan D observasi

Dapat dilihat bahwa hubungan antara kedua nilai tersebut dekat dengan nilai $\mathrm{R}^{2}=0,781$ yang relatif dekat dengan satu. Persamaan D yang dihasilkan akan dapat digunakan untuk memprediksi nilai diameter butir tepung hasil pneumatic drying aktual secara baik.

\section{KESIMPULAN}

Dari hasil penelitian ini dapat disimpulkan bahwa analisis dimensi dapat digunakan untuk memformulasikan hubungan antara sifat fisik tepung hasil pengeringan dengan variabel-variabel proses pengeringan yang dipilih, dimana hubungan tersebut dapat dinyatakan dengan

$$
\begin{aligned}
& F M=12044,8113 \cdot\left(\frac{Q_{i}}{Q_{o}}\right)^{-0,0585} \cdot\left(\frac{V_{u}}{g \cdot \theta}\right)^{-0,3112} \cdot\left(\frac{\theta^{2} \cdot g}{D_{p r}}\right)^{-0,4776} \cdot\left(\frac{T_{u}}{T_{b o}}\right)^{-1,3504} \\
& D=0.104(2)\left\{12044,8113\left(\frac{Q_{i}}{Q o}\right)^{-0,0585}\left(\frac{V_{u}}{g \cdot \theta}\right)^{-0,3112}\left(\frac{\theta^{2} g}{D p r}\right)^{-0,4776}\left(\frac{T_{u}}{T b o}\right)^{-1,3504}\right\}
\end{aligned}
$$

Kedua persamaan mempunyai nilai $\mathrm{R}^{2}$ yang cukup besar sehingga dapat digunakan untuk memprediksi baik nilai kehalusan maupun diameter tepung hasil pengeringan dengan baik. Adapun dimensionless product yang paling berpengaruh terhadap kedua persamaan tersebut adalah $\left(\frac{T_{u}}{T_{b}}\right)$. Persamaanpersamaan tersebut berlaku untuk nilai $\left(\frac{\varepsilon_{\ell}}{\varepsilon_{0}}\right)$ dari $3,136-5,207$,

$\left(\frac{V_{u}}{g . \theta}\right)$ dari $0,152-0,172,\left(\frac{\theta^{2} \cdot g}{D_{p r}}\right)$ dari 4792836,6-4963406,8, dan $\left(\frac{T_{u}}{T_{b}}\right)$ dari 4,714-5,689.

\section{DAFTAR PUSTAKA}

Bunyawanichakul, P., Walker, G.J., Sargison, J.E. dan Doe, P.E. (2007). Modelling and simulation of paddy grain (rice) drying in a simple pneumatic drying. Journal of Biosystem Engineering 96(3): 335-344.

Fumihiko, T., Toshitaka, U. dan Daisuke, H. (2008). Mathematical modeling of pneumatic drying of rice powder. Journal of Food Engineering 88: 492-498. 
Gunter, B. dan Morgado, E. (2003). Dimensional analysis revisited. Journal of Biology Research 36: 405-410.

Henderson, S.M. (1961). Feed grinding studies. Basic observations and challenges on grinding procedure. Journal of Agricultural Engineering 42: 350-352, 364.

Henderson, S.M. dan Perry, R.L. (1976). Agricultural Process Engineering, $3^{\text {rd }}$ Edn. The Avi Publishing Company, Inc., Westport, Connecticut.

Lam, S.H. (2004). Dimensional Analysis. ME351B Fluid Mechanics, Stanford University, Wina.

Mujumdar, A.S. (1987). Handbook of Industrial Drying. Marcel Dekker, Inc., New York and Basel.
Pelegrina, A.H. dan Crapiste, G.H. (2001). Modelling the pneumatic drying of food particles. Journal of Food Engineering 93(2): 151-161.

Randall, A.A. (2000). Dimensional Analysis, Scale Analysis, and Aimilarity Analysis. Departement of Atmospheric Science, Colorado State University, Ford Collins, Colorado.

Sonin, A.A. (2001). The Physical Basic of Dimensional Analysis, $2^{\text {nd }}$ Edn, Departement of Mechanical Engineering, MIT, Cambridge.

Verdijck, G.J.C., Weiss, M. dan Presig, H.A. (1988). Modelling of pneumatic dryer for potato starch. Journal of Food Engineering 37(2): 243-258. 